\title{
A fogágybetegség és a peri-implant betegségek új klasszifikációja
}

\author{
Az American Academy of Periodontology (AAP) \\ és a European Federation of Periodontology (EFP) \\ World Workshop on the Classification of Periodontal and \\ Peri-implant Diseases and Conditions (2017) konszenzus riportja
}

\section{2. rész: A parodontitis klasszifikációja}

DR. GERA ISTVÁN

\begin{abstract}
Az új klasszifikációs rendszer több ponton módosította, illetve felülírta a plakk okozta fogágybetegség 1999-es nevezéktanát és klasszifikációját. A korábban krónikus és agresszív parodontitist egységesen parodontitisnek nevezte el és ezen belül két dimenziós diagnosztikai kategóriát különít el, nevezetesen (staging) stádium és (grading) osztály fokozatot. A stádium (staging) az első vizsgálat során felmért parodontális állapot súlyosságát és a kezelés szempontjából a komplexitását foglalja magába. Az osztály (grading) pedig további információval szolgál a betegség biológiai hátteréről, az anamnézisről, a betegség progressziójáról, a rizikófaktorokról, a további progresszió rizikójáról, a lehetséges kezelési eredményeket negatívan befolyásoló tényezőkről, valamint mindazokról a rizikófaktorokról, amelyeket maga a betegség vagy a parodontális kezelés jelent a páciens általános egészségi állapotára.

A necrotizáló fogágybetegség, amelyhez klinikailag jellemző egyedülálló jelek (papilla necrozis, spontán vérzés és fájdalom) társulnak megváltozott szervezeti immun válasszal, továbbra is a korábbi, 1999-es klasszifikáció diagnózisát használja. Az endo-parodontális léziók körébe az új besorolás azokat a patológiás folyamatokat sorolja, amelyben egy adott fognál a pulpa és a parodontium között valamilyen kommunikációs csatorna nyílik meg. Ez lehet akut és krónikus lefolyású. Ezen belül olyan alcsoportokat állít fel, amelyek hatással vannak a folyamat lefolyására és a kezelési lehetőségekre. A parodontális abscessus olyan akut folyamat, amelyben a sulcus/tasak falszövetében genny gyúlik össze, amely nagyon rapid szöveti destrukciót eredményez és nagy a veszélye a folyamat tovaterjedésének.
\end{abstract}

Kulcsszavak: akut parodontális állapotok, endo-parodontalis léziók, fogágybetegség, necrotizáló gingivitis, necrotizáló parodontitis, parodontális abscessus, parodontitis

\section{Bevezetés}

A parodontitis krónikus, multikauzális gyulladásos betegség, fő oka a disbiotikus biofilm-akkumuláció és jellemzője a fogak rögzítő szöveteinek progresszív, irreverzibilis pusztulása[1]. Vezető tünete a parodontális tapadásveszteség (CAL) és a radiológiailag kimutatható csontpusztulás, az ezzel társuló tasakképződés és ínyvérzés.

A parodontitis komoly népegészségügyi probléma, tekintettel arra, hogy a leggyakoribb bakteriális gyulladásos betegség, amely fogvesztéshez, rágási képtelenséghez, komoly esztétikai hátrányhoz, szociálisan negatív szituációkhoz vezet. Kezelése hosszadalmas és költséges, felnőtt korban a foghiány és később a teljes foghiány vezető oka, és összességében negatív hatása van mind az egyénre, mind pedig az egész társadalomra nézve [2, 3, 4].

A legutóbbi AAP 1999-es klasszifikáció-rendszer a parodontitist a következő kategóriákba sorolta [5]:
- Krónikus parodontitis - olyan destruktív fogágybetegség, amelyet általánosságban lassú progressziója jellemzi [6].

- Agresszív parodontitis - a parodontitis meglehetősen heterogén különböző klinikai formái, elsősorban a fiatalok betegsége, nagyon destruktív és a progressziója általában rapid. Ebbe a kategóriába sorolták a korábbi „early onset” és „rapidly progressing periodontitis" klinikai formákat is [7].

- Parodontitis mint a szisztémás betegségek manifesztációja - nagyon heterogén csoport, amelybe olyan manifeszt szisztémás betegségek tartoznak, amelyek súlyos parodontális gyulladással/pusztulással társulnak [5, 8].

- Nekrotizáló fogágybetegségek - a betegségek azon csoportja, amelynek közös jellemző tünete az íny vagy a parodontális mélyebb szöveteinek nekrózisa [9].

- Parodontium abscessusai - olyan klinikai entitás, amely azonnali speciális ellátást igényel [5]. 
Bár a fenti klasszifikációs rendszer az elmúlt 17 évben megfelelő támpontot adott mind a klinikai gyakorlatban, mind a kutatásokban, azonban egyre több hiányosságára derült fény. Sok volt benne az átfedés, hiányoztak bizonyos patobiológiai alapon megfogalmazott megkülönböztetések [10]. Ennek okán az új osztályozási rendszer, felhasználva mindazokat az elmúlt évtizedben felgyülemlett epidemiológiai adatokat és az etio-petogenezis terén nyert új ismereteket, a munkacsoport öt összefoglaló közleménye alapján a következő jelentős módosításokat javasolta [11].

\section{Az AAP 1999-es klasszifikációs rendszer kritikája és jelentősebb módosításai}

\section{A legnagyobb kritikával a korábbi „,agresszív pa-} rodontitis" kategóriát illették. A kritika alapja, hogy milyen alapon dönthető el, hogy a krónikus és agreszszív parodontitis valóban etiológiai, hisztológiai alapon, valamint a patomechanizmus és a klinikai manifesztáció alapján két különálló betegség lenne? Az 1999-es AAP klasszifikáció szerinti megkülönböztetést nem támasztják alá újabb epidemiológiai és klinikai vizsgálatok. Bár a lokalizált fiatalkori parodontitis esetében igen jellegzetes a klinikai manifesztáció, amelyre jellemző az első moláris és a metszőfogak jellegzetes érintettsége, azonban sem genetikai, mikrobiológiai, sem a patológiai különbségek nem pontosan meghatározhatók. Az sem jósolható meg, hogy kikben alakulhat ki később generalizált parodontitis [12, 13].

a) az egymásnak ellentmondó irodalmi adatok egyre jobban alátámasztják azt a nézetet, hogy az agreszszív parodontitis esetében ez a kategória túlságosan nagy és nehezen definiálható [13].

b) a betegséget soha nem lehetett kezdeti stádiumában diagnosztizálni és utána folyamatosan követni.

c) a különböző követéses vizsgálatokat eltérő időpontokban és különböző népcsoportokban végezték.

Mivel az agresszív parodontitis diagnózisnak jelenleg nincs kellő tudományosan megalapozott bizonyítéka, ezért ez a diagnosztikai kategória a 2017-es klasszifikációs rendszerből kikerült [13].

Egy lényegesen letisztultabb új klasszifikációs sémát dolgoztak ki a 2017-es EFP-AAP klasszifikációs rendszerben $[11,12]$. (1. táblázat $A / B)$

2. Átlagos éves tapadásveszteség. Annak ellenére, hogy a különböző követéses vizsgálatokban az átlagos tapadásveszteségben jelentős különbségek voltak, mindenképpen jogos olyan tapadásveszteség-küszöböket felállítani, amelyek az adott korcsoportban a különböző súlyossági kategóriákat elkülönítik. A legtöbb követéses vizsgálat különböző országokban és etnikai csoportokban különböző átlagos éves tapadásveszteséget mért [14, 15]. Az AAP 1999-es klasszifi- kációja szerinti krónikus és agresszív parodontitis esetében nem volt kimutatható szignifikáns különbség az éves átlagos tapadásveszteség mértékében. Bizonyos vizsgálatok alapján végzett meta-analízis szintén nem erősítette meg, hogy az életkor vagy a dohányzás fontos rizikófaktor lenne az éves átlagos CAL alakulásában, azonban az igazolt, hogy ez a két tényező negatívan befolyásolja a kezelések kiszámíthatóságát és a gyógyulást [13, 16]. Ugyanakkor több követéses vizsgálat mutatta ki, hogy a dohányzás, a gazdasági-szociális helyzet, a korábbi tapadásveszteség, az etnikai hovatartozás, az életkor és a nem, valamint a fogkő jelenléte fokozza az átlagos éves tapadásveszteség mértékét $[17,18,19,20]$.

3. Betegség progresszió. Nincs olyan irodalmi adat, amely akár megerősítené, akár cáfolná azt, hogy az előző klasszifikáció különböző klinikai formáiban szignifikáns különbség lenne a tapadásveszteség progreszsziójának éves mértékében [21].

4. Necrotizáló fogágybetegség vonatkozásában a korábbi klasszifikációs kritériumok megmaradtak, és csak minimális módosításon estek át, elhagyták az „ulceratív” jelzőt [22]. Szisztémás általános tüneteket okozhat, illetve lokálisan a lágyszövetekben terjedhet, további súlyos csont- és izompusztulást okozva (Necrotizáló stomatitis - Noma) [23, 24, 25]. (2. táblázat)

5. Endo-parodontális betegségek. Patológiás kommunikáció jön létre a pulpa és a parodontium között, amely a szövetekben vagy akut, vagy krónikus gyulladást eredményez [26]. A folyamat a tünetek és a kezelési lehetőségek, valamint a folyamat prognózisa alapján sorolható alcsoportokba (pl. gyökérperforáció vagy fraktúra jelenléte, vagy hiánya, parodontitis jelenléte, vagy hiánya). (3. táblázat)

6. Parodontális abscessus leggyakrabban már fennálló parodontális tasakból alakul ki és etiológiai alapon kell klasszifikálni. Jellemzője a tasakfalban kialakuló genny-gyülem, amely nagyon gyors további tapadásveszteséghez vezet és sokszor a fog megtarthatósága is kérdéses [27, 28]. (4. táblázat)

\section{A parodontitis eset-definíciója}

A parodontitis definíciója három pilléren nyugszik:

a) a páciens elsődleges identifikálása, hogy az esete valóban parodontitis-e

b) a parodontitis típusának meghatározása

c) a specifikus klinikai tünetek leírása és azoknak a tényezőknek meghatározása, amelyek a klinikai kezelés sikerét, a prognózist befolyásolják, illetve hatással vannak a szájüreg, valamint az egész szervezet általános állapotára. 
A parodontitis klasszifikációja

- Stádiumok a súlyosság (az interdentális klinikai tapadásveszteség, a radiológiai csonthiány és foghiányok alapján) valamint az esetek bonyolultsága, komplexitása, kiterjedése és a léziók eloszlása szerint

\begin{tabular}{|c|c|c|c|c|c|}
\hline \multicolumn{2}{|c|}{ Parodontitis stádium } & Stádium I & Stádium II & Stádium III & Stádium IV \\
\hline \multirow{3}{*}{ Súlyosság } & $\begin{array}{l}\text { Interdentális CAL } \\
\text { a legsúlyosabb } \\
\text { helyen }\end{array}$ & $1-2 \mathrm{~mm}$ & $3-4 \mathrm{~mm}$ & $>5 \mathrm{~mm}$ & \\
\hline & $\begin{array}{l}\text { Radiológiai } \\
\text { csontvesztés }\end{array}$ & $\begin{array}{l}\text { Koronális } \\
\text { egyharmad } \\
<15 \%\end{array}$ & $\begin{array}{l}\text { Koronális } \\
\text { egyharmad } \\
15-33 \%\end{array}$ & $\begin{array}{l}\text { Eléri a középső harmadot, } \\
\text { vagy azt meghaladja }\end{array}$ & $\begin{array}{l}\text { Eléri a középső harmadot, } \\
\text { vagy azt meghaladja }\end{array}$ \\
\hline & Foghiány & \multicolumn{2}{|c|}{$\begin{array}{l}\text { Nincs parodontális okból } \\
\text { fogvesztés }\end{array}$} & $\begin{array}{l}\text { Parodontitis miatt } \\
\leq 4 \text { foghiány }\end{array}$ & $\begin{array}{l}\text { Parodontitis miatt } \\
\geq 5 \text { foghiány }\end{array}$ \\
\hline Komplexitás & Lokális & $\begin{array}{l}\text { Maximális PPD } \\
\leq 4 \mathrm{~mm} \text {, } \\
\text { többnyire } \\
\text { horizontális } \\
\text { csonthiány }\end{array}$ & $\begin{array}{l}\text { Maximális PPD } \\
\leq 5 \mathrm{~mm} \\
\text { többnyire } \\
\text { horizontális } \\
\text { csonthiány }\end{array}$ & $\begin{array}{l}\text { A Stádium II komlpexitás } \\
\text { mellett PPD } \geq 6 \mathrm{~mm} \\
\text { Verticalis csonthiány } \\
\geq 3 \mathrm{~mm} \\
\text { II-III furcatio lézió } \\
\text { Mérsékelt fogatlan gerinc } \\
\text { hiány }\end{array}$ & $\begin{array}{l}\text { A Stádium III komplexitás mellett } \\
\text { komplex rehabilitációt igényel, } \\
\text { rágófunkció-csökkenés, } \\
\text { secunder occluziós trauma } \\
>2 \text { fogmozgathatóság, } \\
\text { súlyos fogatlan gerinc defektus, } \\
\text { teljes rágófunkció-csökkenés, } \\
\text { fogvándrolás, } \\
\text { kevesebb mint } 20 \text { maradó fog } \\
10 \text { occluziós pár }\end{array}$ \\
\hline $\begin{array}{l}\text { Kiterjedés } \\
\text { és eloszlás }\end{array}$ & $\begin{array}{l}\text { Adjuk hozzá } \\
\text { a stádiumhoz }\end{array}$ & \multicolumn{4}{|c|}{$\begin{array}{l}\text { Minden stádium esetén adjuk meg leírását annak, } \\
\text { hogy a folyamat lokalizált (<30\% fog érintett), generalizált vagy őrlő/metsző fog típusú }\end{array}$} \\
\hline \multicolumn{6}{|c|}{$\begin{array}{l}\text { Az elsődleges stádiumot a klinikai tapadásveszteség (CAL), ha az nem áll rendelkezésre, a radiológiai csonthiány (RBL) } \\
\text { alapján határozzuk meg. A foghiányok és a fogágybetegség okán elveszített fogak száma, amennyiben ez kideríthető, } \\
\text { módosíthatja a besorolást. Az eset komplexitása (pl. furcatio II, III léziók) még viszonylag csekély tapadásveszteség mellett } \\
\text { is a III. vagy IV stádiumba sorolhatja az esetet. A jelentős fog-mobilitás vagy a rágófogak hiánya szintén a IV. stádiumba } \\
\text { sorolja az esetet. Nem minden esetben van jelen az összes komplikációs tényező, azonban ha már egy jelen van, indokolt } \\
\text { az esetet eggyel súlyosabb stádiumba sorolni. Azonban ez a stádiumba sorolás csak kiindulási támpont, amely után alapos } \\
\text { klinikai vizsgálat és megfontolások alapján állítható fel a pontos diagnózis és eset pontos definíciója. A sikeres kezelésen } \\
\text { átesett betegek esetében a CAL és a RBL mindig a meghatározó a stádiumba sorolásban. Amennyiben bizonyos, az eset } \\
\text { komplexitását meghatározó tényezőt sikerült eliminálni, ez sem indokolja, hogy a pácienst enyhébb stádiumba soroljuk, } \\
\text { mivel az alapvető, kiindulási komplikációs tényezőket a fenntartó kezelés során az egész életen át figyelembe kell venni. }\end{array}$} \\
\hline
\end{tabular}

Tonetti MS, Greenwell H, Kornman KS. Staging and grading of periodontitis: Framework and proposal of a new classification and case definition. J Clin Periodontol. 2018; 45 (Suppl 20): S149-S161. alapján

\section{A parodontitis stádiumai és alosztályok}

A parodontitis stádiumait és az osztályozását foglalja össze az 1/A, 1/B táblázat. A stádium meghatározásában döntő szempont a betegség súlyossága és a kezelések várható komplexitása, míg az osztályba sorolás szempontjai: a betegség patobiológiai háttere, az anamnézisen alapuló rizikó- és progresszió-elemzés, a kezelés kimenetelét hátrányosan befolyásoló tényezők elemzése. Továbbá értékelni kell, hogy a parodontális gyulladásnak, vagy a kezelésének milyen hatása lehet, azaz milyen általános rizikót jelent a szervezet általános egészségi állapotára [29].

\section{Milyen vezető tünete alapján diagnosztizálható parodontitis?}

A parodontitis fő tünete a bakteriális biofilm következtében kialakult gyulladás okozta tapadásveszteség. Általában a betegség definíciójában küszöbértéknek tekinthető az egymással érintkező fogak interproximális felszínén fellépő $\geq 2 \mathrm{~mm}$, illetve egymással nem érintkező fogak esetében több mint két fog mellett mérhető $\geq 3 \mathrm{~mm}$ tapadásveszteség. Klinikusok leggyakrabban a klinikai tapadásveszteséget a röntgenfelvételen kimutatható csontvesztés alapján diagnosztizálják 1/A táblázat. A parodontitis klinikailag értelmezhető leírásában szerepelnie kell a pozitív BOP értékek százalékos arányának, valamint egy adott meghatározott küszöbérték (általában $>4$, illetve $>6 \mathrm{~mm}$ ) feletti PPD, és a $>3$, illetve $>5 \mathrm{~mm}$ CAL értékek arányának az összes meglévő foghoz viszonyítva [30]. 
A parodontitis klasszifikációja: osztályba sorolás

- a pato-biológiai jellemzők, rizikófaktorok, a progresszió mértéke, a várható terápiás kiment és a folyamatnak az általános egészségi állapotra gyakorolt hatása alapján

\begin{tabular}{|c|c|c|c|c|c|}
\hline \multicolumn{3}{|c|}{ Parodontitis osztály } & $\begin{array}{l}\text { A osztály } \\
\text { Lassú progresszió }\end{array}$ & $\begin{array}{l}\text { B osztály } \\
\text { Közepes progresszió }\end{array}$ & $\begin{array}{l}\text { Cosztály } \\
\text { Rapid progresszió }\end{array}$ \\
\hline \multirow[b]{3}{*}{$\begin{array}{l}\text { Elsödleges } \\
\text { kritériumok }\end{array}$} & $\begin{array}{l}\text { A progresszió } \\
\text { direkt } \\
\text { bizonyítékai }\end{array}$ & $\begin{array}{l}\text { Longitudinális } \\
\text { adatok, } \\
\text { radiológiai } \\
\text { csontvesztés } \\
\text { tapadásvesztés }\end{array}$ & $\begin{array}{l}\text { Az elmúlt } 5 \text { évben } \\
\text { nem volt } \\
\text { tapadásveszteség }\end{array}$ & $\begin{array}{l}\leq 2 \text { mm tapadásvesztés } \\
\text { az elmúlt } 5 \text { évben }\end{array}$ & $\begin{array}{l}\geq 2 \mathrm{~mm} \text { több } \\
\text { tapadásvesztés az elmúlt } \\
5 \text { évben }\end{array}$ \\
\hline & \multirow[b]{2}{*}{$\begin{array}{l}\text { A progresszió } \\
\text { indirekt } \\
\text { bizonyítékai }\end{array}$} & $\begin{array}{l}E ́ v i \%-o s \\
\text { tapadásveszteség }\end{array}$ & $<0,25$ & $0,25-1,0$ & $>1,0$ \\
\hline & & $\begin{array}{l}\text { Az eset klinikai } \\
\text { formája } \\
\text { (fenotípus) }\end{array}$ & $\begin{array}{l}\text { Nagymennyiségű } \\
\text { supragingivalis } \\
\text { biofilm minimális } \\
\text { tapadásveszteséggel }\end{array}$ & $\begin{array}{l}\text { A supragingivális biofilm } \\
\text { mennyiségével arányos } \\
\text { tapadásveszteség }\end{array}$ & $\begin{array}{l}\text { A supragingivalis biofilm } \\
\text { mennyiség alapján } \\
\text { nem várt, } \\
\text { lényegesen jelentősebb } \\
\text { tapadásveszteség. } \\
\text { Olyan speciális klinikai } \\
\text { tünetek, amelyek rapid, } \\
\text { vagy fiatalkori progresszióra } \\
\text { mutatnak. Őrlő/metsző } \\
\text { típusú destrukció, } \\
\text { vagy a standard } \\
\text { antibakteriális terápiára } \\
\text { nem reagáló eset. }\end{array}$ \\
\hline \multirow{2}{*}{$\begin{array}{l}\text { Az osztályba } \\
\text { sorolást } \\
\text { módosító } \\
\text { tényezók }\end{array}$} & \multirow{2}{*}{ Rizikótényezók } & $\begin{array}{l}\text { Dohányzás } \\
\text { igen/nem }\end{array}$ & Nem dohányzik & Napi $\leq 10$ cigaretta & Napi $\geq 10$ cigaretta \\
\hline & & \begin{tabular}{|l|} 
Diabetes \\
igen/nem
\end{tabular} & $\begin{array}{l}\text { Normoglikémia } \\
\text { Nincs diabetes }\end{array}$ & $\begin{array}{l}\text { HbAlc }<7,0 \% \\
\text { cukorbetegben }\end{array}$ & $\begin{array}{l}\mathrm{HbAlc} \geq 7,0 \% \\
\text { cukorbetegben }\end{array}$ \\
\hline \multicolumn{6}{|c|}{$\begin{array}{l}\text { Az osztályba sorolás a parodontitis progressziójának fokát és mértékét fejezi ki. Az elsődleges kritériumok } \\
\text { a tapadásveszteség direkt vagy indirekt bizonyítékai alapján adottak. Ha direkt bizonyítékok fellelhetők, ezt kell használni, } \\
\text { ha nem, indirekt bizonyítékok alapján kell megítélni - az életkorhoz viszonyított átlagos csontvesztés a legsúlyosabb } \\
\text { állapotban lévő fog mellett (radiológiai csontvesztés a gyökérhossz százalékában kifejezve, osztva a páciens életkorával } \\
\text { - Relatív csontvesztés/életkor). A klinikus elsődlegesen mindig tételezzen fel B osztályú állapotot, és a specifikus } \\
\text { adatok alapján módosíthatja vagy A, vagy C osztályba sorolva. Ha a progresszió elsődleges bizonyítékai alapján az eset } \\
\text { besorolásra került, a feltárt rizikófaktorok szerint ez tovább módosítandó. }\end{array}$} \\
\hline
\end{tabular}

Tonetti MS, Greenwell H, Kornman KS. Staging and grading of periodontitis: Framework and proposal of a new classification and case definition. J Clin Periodontol. 2018; 45 (Suppl 20): S149-S161. alapján

\section{Milyen alapon diagnosztizálható parodontitis?}

1. Interdentális CAL mutatható ki legalább két, egymással nem érintkező fog mellett;

2. Buccalis vagy lingualis $\mathrm{CAL}>3 \mathrm{~mm}$ és $>3 \mathrm{~mm}$ PPD mutatható ki legalább két fog mellett;

3. Azonban a CAL nem minősíthető parodontitisnek a következő esetekben:

a) Gyulladásmentes ínyrecesszió;

b) Fognyaki caries;

c) A második őrlőfog distalis felszínén mért CAL, amely oka vagy a bölcsességfog eltávolítása vagy hibás helyzete;

d) A marginális parodontiumon keresztül drenálódó endodontális léziók;

e) Vertikális gyökérfraktúra.
Az új klasszifikációs rendszer a legújabb patofiziológiai eredmények alapján a következő diagnosztikai kategóriákat ismeri el [13]

(A) Nekrotizáló fogágybetegség (NF)

(B) Parodontitis mint a szisztémás betegségek direkt manifesztációja

(C) Parodontitis

Primer differenciál diagnózis az anamnézis és az NF jellegzetes klinikai tünetei, illetve a szokatlan szisztémás immunológiai és egyéb betegségek jelenléte vagy hiánya alapján állítható fel. A súlyos szisztémás állapotokkal társuló parodontális manifesztációt az alapbetegség alapján az International Statistical Classification of Diseases and Related Health Problems (ICD) kód alap- 
ján kell besorolni. Mindazon fogágybetegség, amely nem esik a fenti két kategóriába, parodontitis terminológiával diagnosztizálható 1/A, 1/B táblázat [31].

Egy adott parodontitis eset tovább kategorizálható a betegség stádiumát, illetve osztályát meghatározó új rendszer szerint. A stádium általában kifejezi a prezentált állapot súlyosságát és komplexitását, az érintett fogak számát és a léziók eloszlását, amelyek mind meghatározhatják a kezelés várható nehézségeit $1 / A$ táblázat. Az osztályba sorolás további információt szolgáltat a betegség anamnézisére, a várható progresszió mértékére az értékelt rizikótényezők alapján, amelyek negatívan befolyásolhatják a parodontális kezelés eredményeit és annak kiszámíthatóságát is 1/B táblázat [29].

\section{Mi különbözteti meg az akut parodontális léziókat a parodontitis egyéb formáitól?}

Az akut parodontális állapotok közös klinikai jellemzője, hogy a parodontális abscessus, az NP és az akut endoparodontális léziók tüneteiben közös [22]:

1. a hirtelen kezdet,

2. a parodontális rögzítő apparátus rapid destrukciója, amely aláhúzza az azonnali oki kezelés szükségességét,

3. fájdalom és díszkomfortérzés, amely miatt a páciens azonnal orvoshoz fordul.

A necrotizáló fogágybetegség (NF) speciális patofiziológiai vonatkozásában valóban jól elkülöníthető betegségcsoport.

A necrotizáló gingivitis (NG) jellegzetes manifesztációja az ínypapilla csúcsán, illetve a szabad ínyszél hám/kötőszöveti rétegében kialakuló szövetszétesés következtében kifejlődő fekély, amelyet szövettanilag nem specifikus gyulladásos infiltrátum vesz körül. A lézió szövettanilag négy rétegre osztható: 1 . felszínen bakteriális zóna, 2 . neutrofil gazdag zóna, 3. neutrifil szegény zóna és 4. spirochaeta infiltrációs zóna 2. táblázat.

A necrotizáló parodontitis (NP) hátterében leggyakrabban súlyos immunhiányos állapotok húzódnak meg. 1. krónikusan súlyos immunhiány pl. AIDS, súlyos fehérjehiányos táplálkozás gyermekkorban, nagyon rossz életkörülmények, súlyos bakteriális vagy vírusfertőzések, amelyek lehetnek életveszélyesek is.

2. Átmeneti vagy mérsékelt immunhiányos állapotok dohányosok, pszicho-szociális stresszhelyzetek felnőtt korban.

\section{A NF betegségek esetdefiníciója}

NG az ínyszél akut gyulladása, amely az ínypapilla fekélyképződésével kezdődik, majd az egész szabad ínyszélen fekély-koszorú alakulhat ki. Rossz szájszaggal, fájdalommal, spontán ínyvérzéssel és hőemelkedéssel társul. A regionális nyirokcsomók megduzzadnak, nyomásra érzékenyek. Fiatal korban erős nyálfolyás fordulhat elő.

NP a marginális parodontium akut gyulladása, amely az ínypapilla fekélyképződésével kezdődik, majd a folyamat gyorsan ráterjed a rögzítő apparátusra, rapid csontrezorbció kíséretében. Rossz szájszaggal, fájdalommal, spontán ínyvérzéssel és hőemelkedéssel társul. A regionális nyirokcsomók megduzzadnak, nyomásra érzékenyek.

NS A parodontitis és a szájnyálkahártya súlyos akut gyulladása, melyben a nekrózis túlterjed a gingiva vonalán, a rögzítő apparátuson és ráterjed a környező lágyszövetekre is. A szövetszétesés következében az alveoláris csont denudálódik, majd sequestrálódik. Ez csak nagyon súlyos immunhiányos állapotokban fordulhat elő. Bizonyos esetekben NS teljesen ép parodontális szövetekben is kifejlődhet, megelőző NG/NP nélkül. Erre jellemző az agranulocytosis vagy a leukémia bizonyos stádiumai. Extrém esetben, elsősorban fiatal, alultáplált, proteinhiányos egyénekben a végstádium, Noma 2. táblázat [13, 22].

\section{Az endo-parodontális lézió speciális pato-biológiai vonatkozásában valóban jól elkülöníthető betegségcsoport}

Az endo-parodontális lézió terminológia olyan patológiás komplikációkat foglal össze, amelyekben vagy a primer pulpaszövet gyulladása következében kialakuló pulpa patológiás folyamata terjed rá a parodontiumra, vagy fordítva, a laterálisan zajló primer parodontális gyulladás érinti a pulpa szöveteket. Elöfordulhat, hogy mind a két folyamat egymástól függetlenül alakul ki. Nincs bizonyíték arra, hogy az endo-parodontális folyamatok speciális patofiziológiás folyamatot képviselnének, ugyanakkor ellátásuk speciális kihívásokat jelent $[13,22]$.

\section{Az endo-parodontális léziók definíciója}

Az endo-parodontális lézió a pulpa és parodontális szövetek közötti patológiás kommunikáció eredménye. Ennek lehet akut és krónikus stádiuma. Vezető tünete a gyökércsúcsot megközelítő mély parodontális tasak és/vagy negatív vitalitás-teszt. Radiológiailag kimutatható csontpusztulás az apex vagy a gyökérelágazás mentén, spontán fájdalom vagy nyomás, kopogtatási érzékenység, purulens suppuratio a tasakból, fokozott fog-mobilitás, sipolyképződés. Traumás vagy iatrogén okokból gyökérperforációval vagy gyökérfraktúrával kell számolni, de előfordulhat külső gyökérresorptio is. Ezek az állapotok nagyon rossz prognózisúak és kérdésessé tehetik a fogak megtarthatóságát 3. táblázat [13, 22]. 
A necrotizáló fogágybetegségek klasszifikációja

\begin{tabular}{|c|c|c|c|}
\hline Kategória & Páciens & Prediszponáló tényezók & Klinikai állapot \\
\hline \multirow{5}{*}{$\begin{array}{l}\text { Necrotizáló fogágybetegség } \\
\text { krónikusan súlyos } \\
\text { immunhiányos betegben }\end{array}$} & \multirow{2}{*}{ Felnőtt } & $\begin{array}{l}\text { HIV+/AIDS CD4 szám } \\
<200, \text { kimutatható vírus }\end{array}$ & \multirow{5}{*}{$\begin{array}{l}\text { NG, NP, NS, Noma } \\
\text { esetleges progresszió }\end{array}$} \\
\hline & & $\begin{array}{l}\text { Egyéb súlyos immun-hiányos állapotok } \\
\text { (immunszupresszio) }\end{array}$ & \\
\hline & \multirow{3}{*}{ Gyermek } & Súlyos alultápláltság /a & \\
\hline & & Extrém életkörülmények /b & \\
\hline & & Súlyos (vírus) infekció /c & \\
\hline \multirow{4}{*}{$\begin{array}{l}\text { Necrotizáló fogágybetegség } \\
\text { átmenetileg vagy mérsékelten } \\
\text { immunhiányos betegben }\end{array}$} & \multirow{3}{*}{ Gingivitises beteg } & $\begin{array}{l}\text { Nem kontrollált tényezők: } \\
\text { stressz, táplálkozás, dohányzás, } \\
\text { rossz szokások }\end{array}$ & \multirow[t]{2}{*}{$\begin{array}{l}\text { Generalizált NG } \\
\text { lehetséges progresszió - NP }\end{array}$} \\
\hline & & Korábban lezajlott NP, ínykráterek & \\
\hline & & $\begin{array}{l}\text { Lokális tényezők, gyökérmorfológia, } \\
\text { fog pozíció }\end{array}$ & $\begin{array}{l}\text { Lokalizált NG } \\
\text { lehetséges progresszió - NP }\end{array}$ \\
\hline & Parodontitises beteg & Általános prediszponáló faktorok & $\begin{array}{l}\text { NG nem gyakori progresszió } \\
\text { NP nem gyakori progresszió }\end{array}$ \\
\hline \multicolumn{4}{|c|}{$\begin{array}{l}\text { NG, necrotizáló gingivitis; NP, necrotizáló parodontitis; NS, necrotizáló stomatitis. } \\
\text { a) a szérum retinoid, ascorbinsav, cink, albumin koncentráció jelentősen csökkent, valamint a nyál albumin, cortisol } \\
\text { és a plasma cortisol szint jelentősen emelkedett } \\
\text { b) rossz életkörülmények, gyermekbetegségek, állatokkal közös élettér, rossz szájhigiénia, tiszta ivóvíz hiánya, } \\
\text { rossz szanitáció, állati vagy emberi ürülékkel való kontaktus } \\
\text { c) Kanyaró, herpes víruscsoport (cytomegalovirus, Epstein-Barr vírus-1, herpes simplex I, II vírus), bárányhimlő, malária, } \\
\text { egyéb lázas betegségek. }\end{array}$} \\
\hline
\end{tabular}

Herrera D, Retamal-Valdes B, Alonso B, Feres M. Acute periodontal lesions (periodontal abscesses and necrotizing periodontal diseases) and endo-periodontal lesions. J Clin Periodontol. 2018; 45 (Suppl 20): S78-S94. alapján

Az endo-parodontális léziók klasszifikációja

\begin{tabular}{|c|c|c|}
\hline \multirow{3}{*}{$\begin{array}{l}\text { Endo-parodontális lézió } \\
\text { gyökérsérüléssel }\end{array}$} & \multicolumn{2}{|c|}{ Gyökérrepedés - gyökérfraktúra } \\
\hline & \multicolumn{2}{|c|}{ Gyökércsatorna-perforáció, pulpakamra-perforáció } \\
\hline & \multicolumn{2}{|c|}{ Külső gyökér-resorptio } \\
\hline \multirow{6}{*}{$\begin{array}{l}\text { Endo-parodontális lézió } \\
\text { gyökérsérülés nélkül }\end{array}$} & \multirow{3}{*}{$\begin{array}{l}\text { Endo-parodontális lézió } \\
\text { fogágybetegben }\end{array}$} & 1. fokozat: keskeny, mély parodontális tasak egy fogfelszínen \\
\hline & & 2. fokozat: széles, mély parodontális tasak egy fogfelszínen \\
\hline & & 3. fokozat: mély parodontális tasak több fogfelszínen \\
\hline & \multirow{3}{*}{$\begin{array}{l}\text { Endo-parodontális lézió } \\
\text { nem fogágybetegben }\end{array}$} & 1. fokozat: keskeny, mély parodontális tasak egy fogfelszínen \\
\hline & & 2. fokozat: széles, mély parodontális tasak egy fogfelszínen \\
\hline & & 3. fokozat: mély parodontális tasak több fogfelszínen \\
\hline
\end{tabular}

Herrera D, Retamal-Valdes B, Alonso B, Feres M. Acute periodontal lesions (periodontal abscesses and necrotizing periodontal diseases) and endo-periodontal lesions. J Clin Periodontol. 2018; 45 (Suppl 20): S78-S94. alapján

\section{Mi különbözteti meg a parodontális abscessust a parodontitis egyéb formáitól?}

A parodontális abscessus etio-patológiai szempontból jól elkülöníthető klinikai entitás. Az abscessus kialakulásában az első kiváltó faktor a tasakfal direkt bakteriális inváziója, vagy esetleg idegentest beékelődés, amely nagyszámú $P M N$ leukocyta és egyéb gyulladásos sejt beáramlását váltja ki. Ha a PMN leukocyták nem képesek a baktériumokat vagy az idegentestet eliminálni, jelentős PMN degranuláció, szöveti szétesés a következmény, ami további PMN beáramlást vált ki és végül gennyképződést eredményez. Ha ez a nagymennyiségű exsudátum nem vezetődik le a sulcus szájadékán keresztül, felgyülemlik és tályog alakul ki. Pato-fiziológiai szempontból ez az állapot abban különbözik a krónikus gyulladástól, hogy az abscessus alacsony pH-ja a környező szövetekben jelentős katabolikus enzim-aktivitást generál, amely csak tovább súlyosbítja a destrukció mértékét $[13,22]$. 
Az abscessus parodontális léziók klasszifikációja (oki tényezők szerint)

\begin{tabular}{|c|c|c|c|}
\hline \multirow{7}{*}{$\begin{array}{l}\text { Parodontális abscessus } \\
\text { fogágybetegben } \\
\text { egy korábban fennálló } \\
\text { tasakban }\end{array}$} & \multirow{3}{*}{ Akut exacerbatio } & Nem kezelt parodontitis & \\
\hline & & Terápia refrakter parodontitis & \\
\hline & & Szuportiv parodontális kezelés & \\
\hline & \multirow{4}{*}{ Parodontális kezelés után } & Depurálás után & \\
\hline & & Parodontális mútét után & \\
\hline & & \multirow{2}{*}{ Gyógyszeres kezelés után } & Szisztémás antibiotikum \\
\hline & & & Egyéb pl. Nifedipine \\
\hline \multirow{9}{*}{$\begin{array}{l}\text { Parodontális abscessus } \\
\text { nem fogágybetegben } \\
\text { - nem kell feltétlenül } \\
\text { korábbi parodontális } \\
\text { tasaknak lenni }\end{array}$} & \multicolumn{2}{|l|}{ Idegentest beékelődés } & $\begin{array}{l}\text { Fogselyem, retractios fonal, } \\
\text { kofferdám, étel }\end{array}$ \\
\hline & \multicolumn{2}{|l|}{ Káros szokások } & Körömrágás, csikorgatás \\
\hline & \multicolumn{2}{|l|}{ Ortodonciai faktorok } & $\begin{array}{l}\text { Ortodonciai tényezők, } \\
\text { keresztharapás }\end{array}$ \\
\hline & \multicolumn{3}{|l|}{ Ínyhiperplázia } \\
\hline & \multirow{5}{*}{ Gyökérfelszín aberrációk } & Súlyos anatómiai eltérések & $\begin{array}{l}\text { Invaginatio, dens in dentem, } \\
\text { odontodysplasia }\end{array}$ \\
\hline & & Kisebb anatómiai eltérések & $\begin{array}{l}\text { Cementgyöngy, zománcgyöngy, } \\
\text { fejlődési barázdák }\end{array}$ \\
\hline & & latrogen tényezők & Perforáció \\
\hline & & Súlyos gyökérkárosodás & Gyökérrepedés, gyökérfraktúra \\
\hline & & \multicolumn{2}{|l|}{ Külső gyökérresorptio } \\
\hline
\end{tabular}

Herrera D, Retamal-Valdes B, Alonso B, Feres M. Acute periodontal lesions (periodontal abscesses and necrotizing periodontal diseases) and endo-periodontal lesions. J Clin Periodontol. 2018; 45 (Suppl 20): S78-S94. alapján

\section{A parodontális abscessus definíciója}

A parodontális abscessus az íny/tasakfalban kialakuló genny-gyülem, amely rapid parodontális destrukciót okoz. A primer klinikai manifesztációja az íny lokális ovális duzzanata a gyökér buccalis vagy palatinalis oldalán, szondázáskor a sulcusból véres váladék és genny ürül. A folyamat fájdalmas és az érintett fog stabilitása is csökken. Parodontális tályog alakulhat ki korábban fennálló tasakból (pl. nem kezelt parodontális tasak), azonban kialakulhat parodontális subgingivális depurálás és kürett után is, amennyiben a tasak legmélyebb részéből a biofilm eltávolítása nem történt meg, a marginális ínyszél azonban gyógyul, a tasakfal szorosabban fekszik a fognyakhoz, ezzel lezárja a sulcusváladék kiáramlásának útját és az exsudátum a tasak mélyén felgyülemlik. Hasonló eset alakulhat ki mechanikai tasakkezelés nélkül alkalmazott szisztémás antibiotikus kezelés következtében is. Ritkán, idegentest beékelődése okán, teljesen ép parodontális állapotban is kifejlődhet parodontális abscessus 4. táblázat [13, 22].

\section{Összefoglalás}

A sorok szerzője, aki megkísérelte röviden összefoglalni a négy szisztémás review-közlemény, valamint a konszenzus-riport közel 90 oldalas anyagát, kénytelen megállapítani, hogy bár a 2017-es klasszifikáció a leg- újabb kutatási eredmények alapján jelentős módosításokat hajtott végre, azonban a klinikusok számára a fogágybetegség klasszifikációja és ennek révén a diagnosztika sok tekintetben lényegesen bonyolultabbá vált, mint korábban [11, 12, 13, 15, 21, 22]. A 2017-es klaszszifikáció sokban visszatért az 1999 előtti AAP klasszifikációkhoz és ezt ötvözte az 1999-es beosztásokkal [33, $34,35]$. Ellentmondásosnak érezzük, hogy az első részben a gingivabetegségek csoportjában az új klasszifikáció a necrotizáló parodontális állapotokat mint nem plakk okozta, specifikus bakteriális infekciónak tünteti fel [36, 37]. Ott is elkülönít necrotizáló gingivitis, necrotizáló parodontitis és necritizáló stomatitis diagnózisokat. Ebben a részben a dentális biofilm okozta fogágybetegség klasszifikációjában szintén hasonló felosztásban tárgyalja a nekrotizáló parodontális folyamatokat. Eddig sokszor kérdéses volt, hogy egy súlyos parodontális állapotot agresszív vagy krónikus, vagy esetleg terápia refracter parodontitisnek diagnosztizáljuk. A jelenlegi beosztásban olyan sok változót kell figyelembe venni (négy stádium, három osztály és emellett nagyon sok egyéb módosító faktor), amelyek egy adott időben fennállhatnak, de egy későbbi időben már nem. Így számomra kérdéses, mennyire lehet érvényes egy első alkalommal felállított diagnózis és kategória a későbbiekben. Az endo-parodontális léziók klasszifikációjában a korábbi Simon [26] vagy Grant-féle beosztás [38], valamint az 1999-es klasszifikáció [5] sok tekintetben 
a gyakorlatban inkább szolgálta a differenciál-diagnózist, egy adott eset kezelési tervének felállítását, mint a jelenlegi [13, 22, 26]. Az 1999-es klasszifikáció megjelenését követően azonnal több kritikai publikáció látott napvilágot [10]. Kíváncsian várjuk, hogy milyen visszhangja lesz a legújabb beosztási rendszernek.

\section{Irodalom}

1. Bartold PM, van Dyke TE: Periodontitis: a host-mediated disruption of microbial homeostasis. Unlearning learned concepts. Periodontol 2000. 2013; 62: 203-217.

2. EKE PI, DYe BA, WEI L, et al.: Prevalence of periodontitis in adults in the United States. J Dent Res. 2012; 91: 914-920.

3. Frencken JE, Sharma P, Stenhouse L, et al.: Global epidemiology of dental caries and severe periodontitis - a comprehensive review. J Clin Periodontol. 2017; 44 (Suppl. 18): S94- S105.

4. Papapanou PN, Susin C: Periodontitis epidemiology: Is periodontitis under-recognized, over-diagnosed, or both? Periodontol 2000. 2017; 75: 45-51.

5. Armitage GC: Development of a classification system for periodontal diseases and conditions. Ann Periodontol. 1999; 4: 1-6.

6. Lindhe J, Ranney R, LAmster I, et al.: Consensus report: chronic periodontitis. Ann Periodontol. 1999; 4: 38-52.

7. Lang N, Bartold PM, Cullinan M, et al.: Consensus report: aggressive periodontitis. Ann Periodontol. 1999; 4: 53-.

8. Albandar JM, Susin C, Hughes FJ: Manifestations of systemic diseases and conditions that affect the periodontal attachment apparatus: Case definitions and diagnostic considerations. J Clin Periodontol. 2018; 45 (Suppl 20): S171-S189.

9. Lang N, Soskolne WA, Greenstein G, et al.: Consensus report: necrotizing periodontal diseases. Ann Periodontol. 1999; 4: 78-.

10. VAN DER WELDEN U: Diagnosis of periodontitis (Letter to the editor). J Clin Periodontol. 2000; 27: 960-961.

11. Caton J, Armitage G, Berglundh T, et al.: A new classification scheme for periodontal and peri-implant diseases and conditions - Introduction and key changes from the 1999 classification. J Clin Periodontol. 2018; 45 (Suppl 20): S1-S8.

12. FINE DH, PATIL AG, Loos BG: Classification and diagnosis of aggressive periodontitis. J Clin Periodontol. 2018; 45 (Suppl 20): S95-S111.

13. Papapanou PN, Sanz M, et al.: Periodontitis: Consensus report of Workgroup 2 of the 2017 World Workshop on the Classification of Periodontal and Peri-Implant Diseases and Conditions. J Clin Periodontol. 2018; 45 (Suppl 20): S162-S170.

14. Schutzhold S, Kocher T, Biffar R, et al.: Changes in prevalence of periodontitis in two German population-based studies. J Clin Periodontol. 2015; 42: 121-130.

15. Billings M, Holtfreter B, Papapanou PN, el al.: Age-dependent distribution of periodontitis in two countries: findings from NHANES 2009-2014 and SHIP-Trend 2008-2012. J Clin Periodontol. 2018; 45 (Suppl 20): S130-S148.

16. Faddy MJ, Cullinan MP, Palmer JE, et al.: Ante-dependence modeling in a longitudinal study of periodontal disease: the effect of age, gender, and smoking status. J Periodontol. 2000; 71: 454-459.

17. Eke PI, Wei L, Thornton-Evans GO, et al.: Risk indicators for periodontitis in US adults: NHANES 2009 to 2012. J Periodontol. 2016; 87: 1174-1185.

18. Papapanou PN, Lindhe J, Sterrett JD, Eneroth L: Considerations on the contribution of ageing to loss of periodontal tissue support. J Clin Periodontol. 1991; 18: 611-615.

19. VAN DYKe TE, SheILesh D: Risk factors for periodontitis. J Int Acad Periodontol. 2005; 7: 3-7.
20. Lang NP, Suvan JE, Tonetti MS: Risk factor assessment tools for the prevention of periodontitis progression a systematic review. J Clin Periodontol. 2015; 42 (Suppl 16): S59-S70.

21. Needleman I, Garcia R, Gkranias N, et al.: Mean annual attachment, bone level and tooth loss: a systematic review. J Clin Periodontol. 2018; 45 (Suppl 20): S112-S129.

22. Herrera D, Retamal-Valdes B, Alonso B, Feres M: Acute periodontal lesions (periodontal abscesses and necrotizing periodontal diseases) and endo-periodontal lesions. J Clin Periodontol. 2018; 45 (Suppl 20): S78-S94.

23. Feller L, Lemmer J: Necrotizing gingivitis as it relates to HIV infection: a review of the literature. Periodontal Prac Today. 2005; 2: $31-37$.

24. Jones AC, Gulley ML, Freedman PD: Necrotizing ulcerative stomatitis in human immunodeficiency virus-seropositive individuals: a review of the histopathologic, immunohistochemical, and virologic characteristics of 18 cases. Oral Surg Oral Med Oral Pathol Oral Radiol Endod. 2000; 89: 323-332.

25. Malberger E: Acute infectious oral necrosis among young children in the Gambia, West-Africa. J Periodontal Res. 1967; 2: 154-162.

26. SimON JH, GLICK DH, Frank AL: The relationship of endodonticperiodontic lesions. J Periodontol. 1972; 43: 202-208.

27. Topoll HH, LANGe DE, Muller RF: Multiple periodontal abscesses after systemic antibiotic therapy. J Clin Periodontol. 1990; 17 : 268-272.

28. CHAN YK, TIEN WS: Clinical parameters of periodontal abscess: a case series of 14 abscesses. Malays Dent J. 2010; 31: 6-7.

29. Tonetti MS, Greenwell H, Kornman KS: Staging and grading of periodontitis: framework and proposal of a new classification and case definition. J Clin Periodontol. 2018; 45 (Suppl 20): S149S161.

30. Holtfreter B, Albandar JM, Dietrich T, et al.: Standards for reporting chronic periodontitis prevalence and severity in epidemiologic studies: proposed standards from the Joint EU/USA Periodontal Epidemiology Working Group. J Clin Periodontol. 2015; 42: 407-412.

31. Albandar JM, Susin C, Hughes FJ: Manifestations of systemic diseases and conditions that affect the periodontal attachment apparatus: case definitions and diagnostic considerations. J Clin Periodontol. 2018; 45 (Suppl 20): S171-S189.

32. Jepsen S, Caton JG, Albandar JM, et al.: Periodontal manifestations of systemic diseases and developmental and acquired conditions: consensus report of workgroup 3 of the 2017 World Workshop on the Classification of Periodontal and Peri-Implant Diseases and Conditions. J Clin Periodontol. 2018; 45 (Suppl 20): S219-S229.

33. CAton J: Periodontal diagnosis and diagnostic aids. In: World Workshop in Clinical Periodontics. Chicago: American Academy of Periodontology; 1989; I1-I22.

34. Consensus report on diagnosis and diagnostic aids. In: World Workshop in Clinical Periodontics. Chicago: American Academy of Periodontology; 1989; I23-I31.

35. Ranney RR. Classification of periodontal disease. Periodontol 2000. 1993; 2: 13-25.

36. Holmstrup P, Plemons J, Meyle J: Non-plaque-induced gingival diseases. J Clin Periodontol. 2018; 45 (Suppl 20): S28-S43.

37. Chapple ILC, Mealey BL, et al.: Periodontal health and gingival diseases and conditions on an intact and a reduced periodontium: Consensus report of workgroup 1 of the 2017 World Workshop on the Classification of Periodontal and Peri-Implant Diseases and Conditions. J Clin Periodontol. 2018; 45 (Suppl 20): S68-S77.

38. Grant DA, Stern IB, Listgarten MA: Periodontics in the tradition of Orban and Gottlieb 1988. CV Mosby Co. 911-920. 


\title{
IstVan GeRA
}

\section{A new classification scheme for periodontal and peri-implant diseases and conditions - Second part: Periodontitis}

\author{
Based on the American Academy of Periodontology (AAP) and the \\ European Federation of Periodontology (EFP) \\ World Workshop on the Classification of Periodontal and Peri-implant Diseases and Conditions (2017) \\ consensus reports
}

The new classification of periodontitis made several changes and updated the AAP 1999 classification system. A universal periodontitis diagnosis has been introduced for the case definitions of all plaque related periodontal diseases. That replaces the previous periodontitis scheme that distinguished "chronic" and "aggressive" periodontitis. All biofilm related periodontal disease under a single category as "periodontitis" are further characterized based on a staging and grading system. Staging expresses the severity of disease at the first clinical examination and also the expected complexity of disease management. The grading evaluates pathobiological features of the disease, the estimated rate of the progression of periodontitis based on the analysis of patient's dental and medical histroy, the risk factors. The risk factors for the further diseases progression and all the factors that might hamper the predictability of therapy should also be evaluated. The periodontal state or the planned invasive periodontal therapy should also be assessed as a potential risk factor for systemic diseases.

The new classification system maintained with some modification the 1999 AAP's classification of Necrotizing Periodontal Diseases (NPD), characterized by typical clinical signs of pain, spontaneous bleeding and papilla necrosis. It is still a distinct category of periodontitis in compromised patients mostly with altered host immune responses. All Endoperiodontal lesions are the consequence of a pathological communication between the pulp and periodontal tissues. This can occur in an acute or a chronic form, and can be further classified according to the clinical signs and symptoms that determines the prognosis and predictability of its management. Periodontal abscesses are acute lesions with localized accumulation of pus within the connective tissues of the periodontal pocket-wall. Its main characteristic is the rapid onset with immediate tissue destruction and the possibility of systemic dissemination.

Keywords: acute periodontal conditions, endo-periodontal lesion, necrotizing gingivitis, necrotizing periodontitis, periodontal abscess, periodontal disease, periodontitis 